\title{
DEVELOPMENT OF SNACK CONTAINING MEAT BY-PRODUCTS AND ITS NUTRITIONAL EVALUATION
}

\author{
Dilip Subba
}

\begin{abstract}
A simple type of snack was developed out of the mixture of wheat flour, cassava flour and pulverized meat offals. Wheat flour, cassava nour and pulverized dehydrated bovine lung, liver, spleen and bone were mixed together with water to form dough. The dough was steamed, cut into thin slices and dried. The snack contained $4.3 \%$ protein, $150 \mathrm{mg}$ lysine $/ 100 \mathrm{~g}$ protein, $5 \mathrm{mg} / 100 \mathrm{~g}$ iron, $151.5 \mathrm{mg} / 100 \mathrm{~g}$ calcium and $20 \mathrm{ug} / 100 \mathrm{~g}$ vitamin $A$.
\end{abstract}

\section{INTRODUCTION}

Feeding the vast population of the world is the major challenge today. Protein malnutrition remains as unsolved nutritional problem of developing countries. Public health problems related with vitamin A and iron deficiency are particularly serious (Edourd, 1985; FAO/WHO/UNU, 1985; Monsen, 1988; Leitzmann, 1990; Carlier et al., 1992; Coutsoudis et al., 1992). Health disorder due to deficiency of calcium also can not be underestimated (Ming, 1986; Heaney, 1986; Desai et al., 1990; Chen et al., 1992).

Meat by-products constitute $50-60 \%$ of the slaughtering yields depending upon animal species. Utilization of meat by-product is important for the viability of meat industry. Meat by-products are used for both edible and inedible purpose. There are some edible meat by-products, which have not been optimally used for human nutrition. Sensory acceptability is the main governing factor in the utilization of meat by-products for human consumption. Liver has appealing taste and it is used in the industrial manufacture of sausage and meat extractive. Spleen and lung are edible but they are not highly acceptable. Spleen is sometimes used in some traditional cooked sausage. Use of spleen and lung in cooked sausage in only partially successful (Bitte et al., 1981; Shaikhova, 1984; Diaz et al., 1990; Zharinov et al., 1994). Porcine and bovine lung is mostly wasted. Liver, lung and spleen are good sources of protein and essential amino acid lysine. Bovine spleen is very rich source of iron. Liver is rich in vitamin A. Bone is good source of dietary calcium. Mihajlovic and petrovic (1984) have recommended use of bone derived calcium phosphate in food.

The objective of the present study was to develop simple type of snack containing bovine lung, spleen, liver and bone and evaluate its nutritional value. 


\section{MATERIAL AND METHOD}

\section{PROCESSING OF MEAT BY-PRODUCTS}

Fresh bovine spleen, lung, blade bone and liver were obtained from the municipality slaughterhouse of Stuttgart, Germany. Covering capsules and adhering fats were removed from the spleen. Trachea, aorta, bronchial tubes and adhering fat were removed from lung and the lung lobes were cut into slices. Lobus sinister laternlis of liver was washed and cut into slices. Spleen, lung and liver were pasteurised by dipping in hot water $\left(90^{\circ} \mathrm{C}\right)$ in a cooking vessel till core temperature reached $70^{\circ} \mathrm{C}$. These were minced through a $3 \mathrm{~mm}$ plate of meat mincer. Spleen was mixed with $500 \mathrm{mg} / \mathrm{Kg}$ sodium bisulphite. The liver was mixed with $0.1 \%$ by weight of dry sausage starter culture (Gewuerzmueller, Germany). The liver was filled in plastic pouch, vacuum packed and allowed to undergo fermentation at room temperature for 26 hour. Sodium bicarbonate solution was then mixed with the liver to raise the $\mathrm{pH}$ to over 6.5 , and the fermentation was further continued for another 30 hours. The fermented liver was again pasteurised. Spleen, lung and liver were spread thin on tray and dried in mechanical dryer at $40^{\circ} \mathrm{C}$. Blade bone was cleaned by scrapping and removing the adhering meat with a knife. Condule and cartilage were cut and removed. Bone was then fed to the double wave breaking machine (Karl Schnell, Germany) to break in small pieces. The bone pieces were reduced to $25 \mathrm{~mm}$ particles with the cutter machine (Karl Schnell, Germany). The bone pieces were cooked in boiling water for about $1 \mathrm{~h}$, after which they were washed with hot water. After drying in hot air the bone pieces were fed again to the cutter machine and reduced in size to $3 \mathrm{~mm}$, which were further ground to $<0.25 \mathrm{~mm}$ size with a grinding mill (Retsch GmbH \& Co. KG, Germany).

These prepared dry meat by-products were mixed in the proportion of spleen (10): lung (50): liver (50): bone (10). This is henceforth called mixture of meat by-products.

\section{Preparation OF SNACK}

Ingredients used for the snack preparation were obtained from the local market. Dry ingredients were mixed in a Hobart mixer. Water was added and dough was prepared. The dough was filled in a tray $(6 \mathrm{~mm}$ depth) and steamed $\left(97^{\circ} \mathrm{C}\right)$ in a cooking vat for $1 \mathrm{~h}$. It was left overnight in cold room to improve firmness and slicing property. It was then sliced in thin strips $(1.5 \mathrm{~mm}$ thick) with a meat slicer which were then dried in air $\left(25^{\circ} \mathrm{C}\right.$ temp. and $\left.33 \% \mathrm{Rh}\right)$ in a mechanical dryer for $4 \mathrm{~h}$. The formulation of snack is presented in Table 1.

\section{SENSORY TEST}

The snack was fried in oil $\left(190^{\circ} \mathrm{C}, 100-120 \mathrm{sec}\right)$ until light brown in colour and presented to the test panel consisting of 28 university students. The test panel evaluated colour and appearance, texture, taste attributes and overall acceptability of the samples according to a 9 point hedonic scale as following 
like extremely, 9; like very much, 8; like moderately, 7; like slightly, 6; neither like nor dislike, 5; dislike slightly, 4; dislike moderately, 3; dislike very much, 2; dislike extremely, 1 . The acceptability of the snack was decided on the basis as described by Fliedner and Wilhelmi (1989). The product which obtained $80 \%$ of the scores in the "like (6-9 points)" hedonic region was considered "acceptable".

\section{Chemical TEST}

Moisture, protein, ash, crude fat and vitamin A were determined in compatibility with the official analytical methods of Federal Republic of Germany (Amtliche Sammlung von Untersuchungsverfahren nach § 35 LMBG, 1987). Amino acid was determined by the following method: Weighed 5-10 mg sample powder in a reagent glass. After the addition of $1 \mathrm{ml}$ of $6 \mathrm{NHCI}$ the reagent glass was heat sealed under vacuum and protective nitrogen gas. The sample

Table 1 : Formulation of Snack

\begin{tabular}{|l|c|}
\hline \multicolumn{1}{|c|}{ Ingredient } & Parts by weight \\
\hline Cassava flour & 100 \\
\hline Wheat flour (Type 405) & 20 \\
\hline Mixture of meat by-products & 4.8 \\
\hline Onion powder & 0.12 \\
\hline Garlic powder & 0.06 \\
\hline Paprika powder & 0.24 \\
\hline Monosodium glutamate & 0.06 \\
\hline Salt & 2.4 \\
\hline
\end{tabular}

was hydrolysed at $110^{\circ} \mathrm{C}$ for $24 \mathrm{~h}$ and subsequently $\mathrm{HCL}$ was removed in a rotating evaporator. The residue was taken up in $1 \mathrm{ml}$ of buffer (sodium acetate/acetic acid/formic acid, $\mathrm{pH}$ adjusted to 3.4, 3.6, 5.4 and 11). Amino acids in hydrolysate were determined by Biotronik LC 3000 amino acid analyser under following conditions : Flow rate of buffer: $0.2 \mathrm{ml} / \mathrm{min}$; Flow time of buffer: 49 min separation time and $24 \mathrm{~min}$ regeneration time; Sample volume: $20 \mu \mathrm{l}$; Column, internal diameter and height: Polymer of cation exchanger, $4 \mathrm{~mm}$ and 14 $\mathrm{cm}$; Derivatising reagent: Ninhydrin

The samples of spleen and liver for iron estimation, and the sample of bone powder for calcium estimation were digested in accordance with the official analytical methods of Federal Republic of Germany (Amtliche Sammlung von Untersuchungsverfahren nach §35 LMBG). Iton and calcium in wheat flour, cassava flour and snacks were analysed as following: A $35 \mathrm{ml}$ of acid mixture 


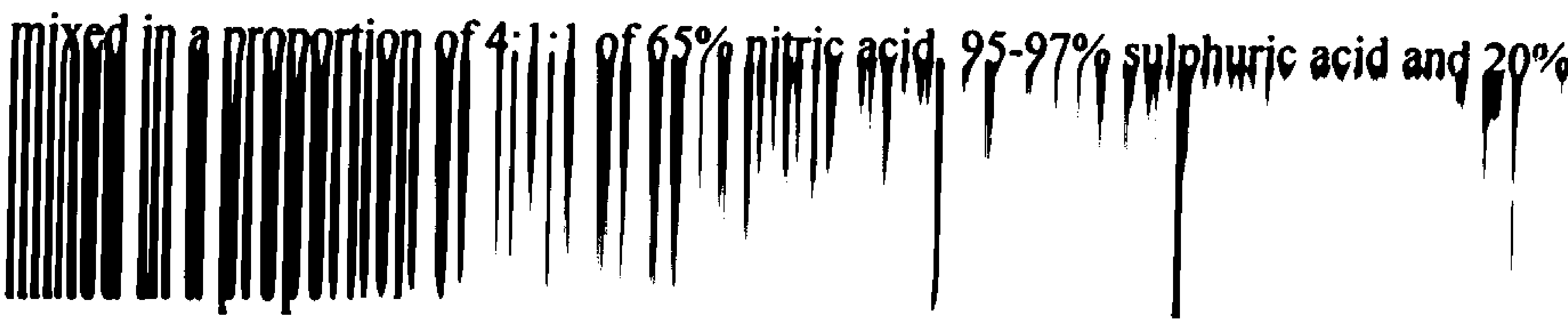

hypochloric acid was added to the sample and the digestion was carried out as per the following heating programmes:

Wheat and cassava flour: $50^{\circ} \mathrm{C} 1 \mathrm{~h} 75^{\circ} \mathrm{C} \cdot \min , 100^{\circ} \mathrm{C} 2 \mathrm{~h}, 150^{\circ} \mathrm{C} 1 \mathrm{~h}$; Snack samples : $50^{\circ} \mathrm{C} 20 \mathrm{~min}, 75^{\circ} \mathrm{C} 20 \mathrm{~min}, 100^{\circ} \mathrm{C} 2 \mathrm{~h}, 150^{\circ} \mathrm{C} 1 \mathrm{~h}$.

After cooling (fat removal, whenever required) suitable dilutions were prepared. Interference of phosphorus to calcium was prevented by adding a suitable amount of $5 \% \mathrm{LaCl}_{3}$ solution. Iron and calcium were measured by atomic absorption spectrophotometry (AAS) according to the official analytical methods of Federal Republic of Germany (Amtliche Sammlung von Untersuchungsverfahren nach $\S 35$ LMBG). The concentration of iron and calcium were measured by atomic absorption spectrophotometer (Perkin Elmer, Model 3030) at $248.3 \mathrm{~mm}$ and $422.7 \mathrm{~mm}$ respectively either directly or with the help of the addition method.

\section{RESULTS AND DISCUSSION}

The summary of the sensory test results is presented in Table 2. The texture of the snack was liked by $96 \%$ of the panellists. The product was well expanded and had a crisp and light bite. The taste was liked by $82 \%$ of the test panellists. The results of the sensory test showed that taste and texture of the snack was acceptable. Only $57 \%$ of the panellists liked the colour. The colour of the snack was brown to dark and might not have been liked by all panellists.

Table 2: Sensory Quality of Snack

\begin{tabular}{|l|c|}
\hline Sensory attribute & \% panellists liking the given sensory attribute \\
\hline Taste & 82 \\
\hline Texture & 96 \\
\hline Colour and appearance & 57 \\
\hline
\end{tabular}

The most frequent hedonic point assigned by the panellists to various sensory attributes is presented in Table 3 . It showed that most of the sensory test participants liked moderately colour and appearance, texture and taste.

Table 3: Most frequently assigned hedonic points to snack $(n=28)$

\begin{tabular}{|l|l|}
\hline Colour and appearance & 7 \\
\hline Texture & 7 \\
\hline Taste & 7 \\
\hline Overall acceptability & 7 \\
\hline
\end{tabular}


The nutritional composition of the prepared meat by-products is presented in Table 4. The processed lung, liver and spleen contained very high protein. Bone protein is nutritionally not important. Lung. liver and spleen are found as excellent sources of lysine. Spleen containing $302 \mathrm{mg}$ iron in $100 \mathrm{~g}$ was found to be very rich source of dietary iron. Meat iron is physiologically more valuable than elemental iron that is normally used for iron enrichment in food. The processed bone contained $24.6 \%$ calcium. The chemical composition of the snack

Table 4: Nutritional Composition of Processed Meat by-products

\begin{tabular}{|l|l|l|l|l|l|l|l|}
\hline $\begin{array}{l}\text { Meat by- } \\
\text { product }\end{array}$ & $\begin{array}{l}\text { moisture } \\
(\%)\end{array}$ & $\begin{array}{l}\text { protein } \\
(\%)\end{array}$ & $\begin{array}{l}\text { lysine }(\mathrm{g} / 100 \mathrm{~g} \\
\text { protein })\end{array}$ & $\begin{array}{l}\text { fat } \\
(\%)\end{array}$ & $\begin{array}{l}\text { iron } \\
(\mathrm{mg} / 100 \mathrm{~g})\end{array}$ & $\begin{array}{l}\text { vitamin A } \\
(\mathrm{mg} / 100 \mathrm{~g})\end{array}$ & $\begin{array}{l}\text { calcium } \\
(\%)\end{array}$ \\
\hline Llung & 7.6 & 77.7 & 7.1 & 9.2 & $\mathrm{ND}$ & $\mathrm{ND}$ & ND \\
\hline Liver & 7.3 & 64.1 & 7.7 & 10.5 & 13 & 25.8 & ND \\
\hline Splcen & 5.6 & 79.2 & 8.0 & 6.9 & 302 & ND & ND \\
\hline Bone & 4.4 & 26.1 & ND & 1.4 & ND & ND & 24.6 \\
\hline
\end{tabular}

Note:- ND = not determined

is presented in Table 5. From the same table nutritive value of the snack can be compared with the mixture of cassava and wheat flour. It can be seen that the content of protein, iron, calcium and lysine is higher in the snack than the mixture of cassava and wheat flour. It showed that the addition of meat byproducts to cereal and root tuber like cassava improved their nutritional quality in terms of protein. lysine. iron and calcium content. Root tubers in general contain low amount of protein. Fresh cassava contains 1\% protein (Souci et al., 1989/90). The work showed that sensorically acceptable snack with improved nutritive value could be made from the mixture of cassava, wheat flour and meat by-products. Nutrition of low income developing countries is cereal-based. Lysine is first limiting amino acid in cereals. A survey showed that the small children of the developing countries did not get adequate supply of lysine (FAO/WHO/UNU, 1985).

Table 5: Chemical Composition of the Mixture of Wheat and Cassava Flour and Snack

\begin{tabular}{|l|c|c|}
\hline \multicolumn{1}{|c|}{ Parameter } & $\begin{array}{c}\text { Mixture of Wheat and } \\
\text { Cassava Flour }\end{array}$ & Snack \\
\hline Moisture (\%) & 12.73 & 12.30 \\
\hline Protein (\%) & 1.78 & 4.34 \\
\hline Fat $(\%)$ & ND & 0.27 \\
\hline Ash $(\%)$ & ND & 2.35 \\
\hline Iron $(\mathrm{mg} / 100 \mathrm{~g})$ & 0.52 & 5.09 \\
\hline Calcium $(\mathrm{mg} / 100 \mathrm{~g})$ & 63 & 151.58 \\
\hline Lysine $(\mathrm{mg} / 100 \mathrm{~g})$ & 32 & 150 \\
\hline Vitamin A $(\mu \mathrm{g} / 100 \mathrm{~g})$ & $\mathrm{ND}$ & 20 \\
\hline
\end{tabular}

Note: $-\mathrm{ND}=$ not determined 


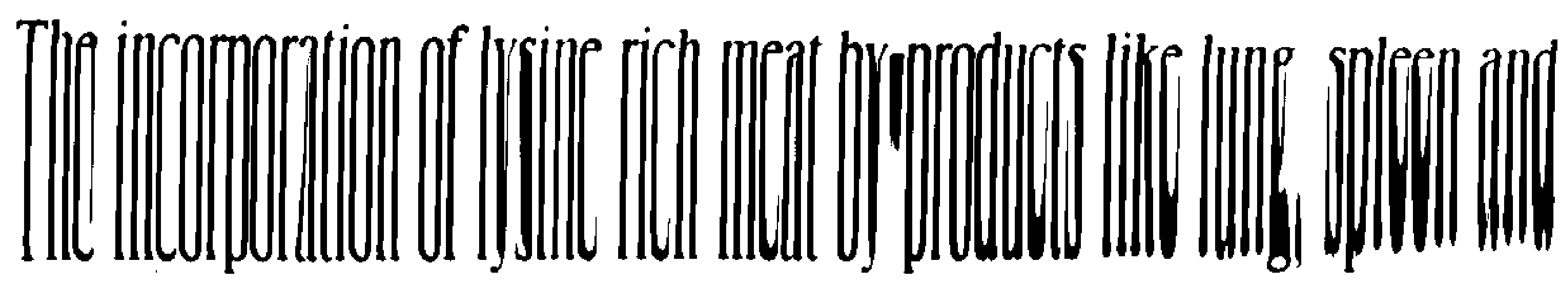

liver in cereal based formulated food like snack can improve lysine intake in the small children. Similarly, use of beef spleen in the formulated food can be helpful in reducing anaemic health problem. Bone powder may be used for calcium supplementation in food to increase its dietary intake.

\section{WORKS CITED}

Amtliche Sammlung van Untersuchungverfahren nach § 35 LMBG. Beuth Verlag GmbH. Berling/Koln, 1987.

Bitte, R.J., Graham, P.P., Young, R.W. \& Bovard, K.P. (1981), Mechanically separated spleen: Its composition and protein efficiency ration J Food Sci 46, 336.

Carlier, C., Etchepare, M., Ceccon, J.F. \& Manesme, O.A. (1992), Assessment of the vitamin A status of preschool and age children during a cross-sectional study. Int J Vitam Jutr Res 62, 209.

Chen, N., Gensheng, Z. \& Lianji, M. (1992), A study on processing technology of children nutritional sausage. Proc $38^{\text {th }}$ Int Congr Meat Sci Tech, clermongFerrand, France. 1099.

Coutsoudis, A., Zwane, M., Coovadia, H.M. \& Gouws, E. (1992), Dietary intake of vitamin A in preschool children in Umlazi, South Africa. Int J Nutr Res 62, 3.

Desai, I.D., Doell, A.M., Officiati, S.A., Bianco, A.M., Van Severen, Y., Desai, M.I. \& Dutra de Oliveira, J.E. (1990), Nutritional needs assessment of rural agricultural migrants of Southern Brazil: Designing, implementing and evaluating a nutrition education program. World Rev Nutr Diet 61, 64 .

Diaz, R., Rodrignez, C., Hombre, R.D., Casals, C., A.varez, J. \& Duquesne, J. (1990), Use of slaughtering by-products blends in sausage manufacture. proc $36^{\text {th }}$ Int Congr Meat Sci Tech, Havana, Cuba, Aug 27-Sept 1. 2, 366.

Edourd, S. (1985), The fifth world food survey. Food and Agriculture Organisation, Rome, Italy.

Fliedner, I. \& Wilhelmi, F. (1989), Grundlagen and prufverfahren der lebensmittelsensorik. Behr's Verlag.

FAO/WHO/UNU (1989), Energy and protein requirements. Tech. Rep. Ser. No. 724, world Health Organisation, Geneva, Switzerland.

Heaney, R.P. (1986), Osteoporosis: The need and opportunity for calcium fortification. Cereal FW 31, 349

Leitzman, C. (1990), qualitative Mangelernahung in Entwicklungslandern, AID verbrauchersdienst $35,120$. 
Milajlovic, B. \& Pertovic, N. (1984), Potential for and trends in the use of bones of slaughter animals as raw material. Technologija Mesa 24 (10). 274-278. In: FSTA Vol 16 (1984), No. 11, 11 S 2126.

Ming C.C. (1986), The national nutritional survey of china, 1982: Summary results. Food Nutr 12, 58.

Monsen, E.R. (1988), Protein-iron interactions: Influences on absorption, metabolism and status. In: Nutrient interactions (C.E. Bodwell and J.W. Erdman, Jr., eds.).

Shaikhova, G.I. (1984), Nutritional evaluation of vew sausage types. FSTA vol. 16, No. 11, aa s 2205 .

Souci, S.W., Fachmann, W. \& Kraut, H. (1989/90), Food composition and nutritional tables. Wissenschaftliche Verlagsgesellschaft mbH Stuttgart.

Zarinov, A.I., Upyrev, A.A. \& Madaliev, I.K. (1994), Unconventional products form bovine lungs and pig skin. Myasnaya Promyshlennost No. 2,9. In: FSTA Vol 26 (1994), No. 3, 3 S 3. 